\title{
Analysis of the Differences in Expenditure Levels of Participants at the 2014 Asian Basketball League in Ho Chi Minh City
}

\author{
Lam Quang Thanh ${ }^{1}$, Nguyen Hoang Minh Thuan ${ }^{2}$ and Nguyen Thanh $\mathrm{Tu}^{2}$ \\ 1. Vietnam Sport Science Institute, Vietnam Sports Administration, Ha Noi Capital 100000, Viet Nam \\ 2. Department of Sport Management, University of Sport Hochiminh City, Ho Chi Minh City 700000, Viet Nam
}

\begin{abstract}
Research focuses on studying the economic impacts of 2014 Asian Basketball League in Ho Chi Minh City (hereinafter referred as ABL 2014) with respect to direct expenditure of all types of participants, including organizers, coaches/athletes, journalists/communicators, audiences, etc. Research was implemented with 920 subjects, including 48 members of the organizing committee, 56 coaches/athletes, 800 audiences and 16 members of journal and media teams.
\end{abstract}

Key words: Differences, level of expenditure, participants.

\section{Introduction}

In Vietnam, nowadays, with the policy on sport socialization, there have been lots of positive changes in sports; many enterprises make large investment in sports, which leads to the emerging of many intermediaries and sport marketing companies; their income from sport leagues also starts increasing. From both theoretical and practical perspectives, the organization of sport leagues plays a very important role in such development, especially in terms of sport economic development for raising living standards as well as mitigating current social issues. Ho Chi Minh City is especially one of the major economic, cultural, social and scientific centers of the country. With its advantages of qualified facilities, modern traffic systems, the leading shopping and recreational centers, Ho Chi Minh City is always chosen to be the venue of many important sport leagues, the favorite venue of organizers, athletes and audiences everywhere.

One of the sport leagues in Ho Chi Minh City which

Corresponding author: Lam Quang Thanh, Ph.D., associate professor, research filed: sport management. currently attracts much public attention is Asian Basketball League (ABL). Although the league has been recently established in 2009, it has attracted much attention from basketball fans all across Southeast Asian countries whose teams participate in the league. Vietnam Basketball first took part in the league in 2012 with Saigon Heat as the representative team. ABL has the participation of those leading professional basketball teams from 6 countries in Southeast Asia: Thailand, Philippines, Indonesia, Malaysia, Singapore and Vietnam. One special thing is that all matches of ABL are broadcasted live on ESPN, a famous Asian sport channel. ABL 2014 started on July 16th 2014 and ended on October 26th 2014. All matches of ABL 2014 were at Maple Leaf Gymnasium-Canadian International School, Ho Chi Minh City from July 19th 2014.

Research is aimed to analyze the differences in levels of expenditure of participants at ABL 2014, which then acts as the objective basis of assessment for organizers in order to suggest solutions for expenditure expansion of these participant groups in the following seasons. 


\section{Methodology}

Methods of literature review, sociological investigation and statistics.

\section{Research Tool}

Survey questionnaire form based on the research framework, survey questionnaire form of other published papers in the world and in Vietnam [2, 5, 6]. And in this article we have to use the VND/USD exchange rate of $(21,000 \mathrm{VND}=1 \mathrm{USD})$.

Survey questionnaire form comprises of two parts:

Part I: Information on types of participants of ABL 2014, including: Admission fee/entrance fee; Food cost inside the gymnasium; Food cost outside the gymnasium; Accommodation cost; Shopping cost: clothes, souvenirs, presents and so on; Entertainment cost at nights: music concerts, clubs, bars, cafe with friends and so on; Transportation cost: gas, petroleum, parking, repairs, car or motorbike hire, flight costs, public transportation cost and so on; Sightseeing cost at tourist attractions in Ho Chi Minh City; Other expenses.

Part II: Personal information of participants of ABL 2014, including: Gender; Age; Marital status; Education; Occupation; Monthly income; Address.

Research subjects: the differences of participants of ABL 2014. Research objects: organizing committee, coaches/athletes, journalists/media teams, audiences.

\section{Results}

\subsection{Economic Impacts of ABL 2014}

There are several studies that have investigated the specific evaluation of sport leagues' economic impacts $[2,5,6]$. In order to evaluate the economic impacts of ABL 2014, it is necessary to determine the total income of participants by this formula:

Direct expense $=$ Average expense $\times$ Number of days in the stay $\times$ Number of daily participants

After the calculation of direct expense of each participant group, we continue calculating the overall expense of all participants in order to evaluate the economic impact of ABL 2014. This formula is applied to calculate the economic impact of ABL 2014:

Economic impact $=$ Direct expense of organizing committee + Direct expense of coaches/athletes + Direct expense of audiences + Direct expense of journalists/media teams.

Applying the formula above, we come up with the result of economic impact, as follows:

Economic impact $=153,691+399,766.2+$ $697,025.6+15,077.0=1,265,559.80$ USD

Based on the final result of the overall expense of all participants of ABL 2014, it can be seen that the league has brought a new income, which is $1,265,559.80$ USD for the budget of Ho Chi Minh City in the year of 2014 (Table 1).

According to the comparison of the overall expense of each participant group, audience group has the largest constitution with $55.1 \%$; next is coach/athlete group with the constitution of $31.6 \%$; organizing committee group constitutes $12.1 \%$; and the smallest constitution belongs to journalist/media team group with only $1.2 \%$.

\subsection{Analysis on the Differences in Expenditure Levels of Participants of ABL 2014}

The method of one-way ANOVA is applied in order to analyze the differences in expenditure levels of these groups: organizing committee, coaches/athletes, journalists/media teams and audiences participating in ABL 2014.

With the significance level of $95 \%$, which means that the difference in expenditure levels of participant groups is statistically significant, the following result has been collected after applying Sheffe method (Table 2).

"Admission fee/entrance fee" is compulsory; therefore, it is not included in the analysis.

In terms of "food cost at the gymnasium", there is a statistical difference among the expenditure levels of participant groups with $\mathrm{P}=0.000<0.05$. More specifically, we have: (1) Audience group has the lower 
Table 1 Direct expense of participant groups (Unit: USD).

\begin{tabular}{llllll}
\hline \multirow{2}{*}{ Types of expense } & \multicolumn{5}{c}{ Participant groups } \\
\cline { 2 - 5 } & Organizing committee & Coach/athlete & Audience & Journalist/media team & Direct expense \\
\hline Transportation cost & 5,815 & $33,895.4$ & $237,948.7$ & 759.0 & $225,418.1$ \\
Admission fee/ticket fee & 0 & 0.0 & $225,641.0$ & 0.0 & $204,894.0$ \\
Accommodation cost & 57,692 & $104,012.3$ & $35,692.3$ & $7,497.4$ & $166,166.5$ \\
Shopping cost & 16,708 & $89,058.5$ & $58,666.7$ & $1,733.3$ & $107,181.3$ \\
Night entertainment cost & 9,692 & $56,658.5$ & $39,384.6$ & $1,446.2$ & $97,560.60$ \\
Sightseeing cost at tourist & 30,738 & $35,889.2$ & $30,359.0$ & 574.4 & $78,086.3$ \\
attractions & 8,954 & $36,886.2$ & $30,769.2$ & $1,476.9$ & $71,407.2$ \\
Food cost outside the & 15,600 & $28,412.3$ & $26,256.4$ & $1,138.5$ & $36,204.80$ \\
gymnasium & 8,492 & $14,953.8$ & $12,307.7$ & 451.3 & $1,265,559.80$ \\
Other expense & 153,691 & $399,766.2$ & $697,025.6$ & $15,077.0$ & \\
Food cost at the & & & & & \\
gymnasium & & & & \\
Total & & & &
\end{tabular}

Table 2 Difference on the expenditure levels of participant groups.

\begin{tabular}{|c|c|c|c|}
\hline Type of expenses & $\mathrm{F}$ & $\mathrm{P}$ & Post-hoc (Scheffe) \\
\hline Food cost at the gymnasium & 30,784 & 0.000 & $\begin{array}{l}\mu_{1}<\left(\mu_{2}, \mu_{3}, \mu_{4}\right) \\
\mu_{2}>\left(\mu_{1}, \mu_{4}\right) \\
\mu_{4}>\mu_{1}\end{array}$ \\
\hline Food cost outside the gymnasium & 27,497 & 0.000 & $\begin{array}{l}\mu_{1}<\mu_{2} \\
\mu_{2}>\left(\mu_{1}, \mu_{3}\right) \\
\mu_{3}>\mu_{2}\end{array}$ \\
\hline Accommodation cost & 91,028 & 0.000 & $\begin{array}{l}\mu_{1}<\left(\mu_{2}, \mu_{3}, \mu_{4}\right) \\
\mu_{1}<\mu_{2}\end{array}$ \\
\hline Shopping cost & 14,939 & 0.000 & $\begin{array}{l}\mu_{3}<\mu_{2} \\
\mu_{2}>\left(\mu_{1}, \mu_{4}\right) \\
\mu_{4}<\mu_{2}\end{array}$ \\
\hline Night entertainment cost & 15,881 & .000 & $\begin{array}{l}\mu_{1}<\mu_{2} \\
\mu_{2}>\left(\mu_{1}, \mu_{4}\right) \\
\mu_{3}<\mu_{2} \\
\mu_{4}<\mu_{2}\end{array}$ \\
\hline Transportation cost & 11,697 & 0.000 & $\begin{array}{l}\mu_{1}>\left(\mu_{2}, \mu_{3}\right) \\
\mu_{2}<\mu_{1} \\
\mu_{3}<\mu_{1}\end{array}$ \\
\hline Sightseeing cost at tourist attractions & 9,497 & 0.000 & $\mu_{1}<\mu_{3}$ \\
\hline Other expense & 6,215 & 0.000 & $\mu_{1}<\mu_{2}$ \\
\hline
\end{tabular}

Note: $\mu_{1}$ : Audience $\mu_{2}$ : Coach/athlete $\mu_{3}$ : Organizing committee $\mu_{4}$ : Journalist/Media team

expenditure level than organizing committee, audience, and coach/athlete group; (2) Coach/athlete group has the higher level of expenditure compared to audiences and journalists/media teams; (3) Journalist/media team group has the higher level of expenditure compared to audiences.

For "food cost outside the gymnasium" $(P=0.000<$ $0.05)$, the difference in expenditure levels of participant groups is statistically significant. More specifically, we have: (1) Audience group has the lower expenditure level than coach/athlete group; (2)
Coach/athlete group has the higher level of expenditure compared to audiences and organizing committee; (3) Organizing committee has the higher expenditure level than coach/athlete group.

For "Accommodation cost" $(P=0.000<0.05)$, the difference in expenditure levels of participant groups is statistically significant. More specifically, we have: Audience group has the lower expenditure level than organizing committee, audience, and coach/athlete group.

For "shopping cost" $(P=0.000<0.05)$, the 
difference in expenditure levels of participant groups is statistically significant. More specifically, we have: (1) Audience group has the lower expenditure level than coach/athlete group; (2) Organizing committee has the higher level of expenditure compared to coach/athlete group; (3) Coach/athlete group has the higher expenditure level than audience and journalist/media team group; (4) Journalist/media team group has the higher expenditure than coach/athlete group.

For "night entertainment cost" $(P=0.000<0.05)$, the difference in expenditure levels of participant groups is statistically significant. More specifically, we have: (1) Audience group has the lower expenditure level than coach/athlete group; (2) Coach/athlete group has the higher expenditure level than audience and journalist/media team group; (3) Organizing committee has the higher level of expenditure compared to coach/athlete group; (4) Journalist/media team group has the higher expenditure than coach/athlete group.

For "transportation cost" $(P=0.000<0.05)$, the difference in expenditure levels of participant groups is statistically significant. More specifically, we have: (1) Audience group has the higher expenditure level than coach/athlete group and organizing committee; (2) Coach/athlete group has the lower expenditure level than audience; (3) Organizing committee has the higher level of expenditure compared to audience group.

For "sightseeing cost" $(P=0.000<0.05)$, the difference in expenditure levels of participant groups is statistically significant. More specifically, we have: Audience group has the lower expenditure level than organizing committee.

For "other expenses" $(P=0.000<0.05)$, the difference in expenditure levels of participant groups is statistically significant. More specifically, we have: Audience group has the lower expenditure level than coach/athlete group.

Furthermore, we also find out the statistically insignificant difference in expenditure levels of participant group at ABL 2014, as follows:

For "food cost at the gymnasium", the difference in expenditure levels is statistically insignificant among these groups: (1) Coach/athlete group has the lower level of expenditure compared to organizing committee and journalist/media team group; (2) Organizing committee has the higher expenditure level than coach/athlete and journalist/media team group; (3) Journalist/media team group has the lower level of expenditure compared to coach/athlete and organizing committee.

For "food cost outside the gymnasium", the difference in expenditure levels is statistically insignificant among these groups: (1) Audience group has the lower expenditure level than coach/athlete and journalist/media team group; (2) Coach/athlete group has the higher level of expenditure compared to organizing committee.

For "Accommodation cost", the difference in expenditure levels is statistically insignificant among these groups: (1) Coach/athlete group has the higher expenditure level than organizing committee and the lower expenditure level than organizing committee; (2) Organizing committee has the lower expenditure level than coach/athlete and journalist/media team group; (3) Journalist/media team group has the higher expenditure level than coach/athlete and organizing committee group.

For "shopping cost", the difference in expenditure levels is statistically insignificant among these groups: (1) Audience group has the lower expenditure level than coach/athlete and journalist/media team group; (2) Organizing committee has the higher level of expenditure compared to audience and journalist/media team group; (3) Journalist/media team group has the higher expenditure level than audience and the lower expenditure level compared to organizing committee.

For "night entertainment cost" $(P=0.000<0.05)$, the difference in expenditure levels of participant groups is statistically significant. More specifically, we 
have: (1) Audience group has the lower expenditure level than organizing committee and journalist/media team group; (2) Organizing committee has the higher expenditure level than audience and journalist/media team group; (3) Journalist/media team group has the higher level of expenditure compared to audience and organizing committee group.

For "transportation cost", the difference in expenditure levels is statistically insignificant among these groups: (1) Audience group has the higher expenditure level than journalist/media team group; (2) Coach/athlete group has the higher expenditure level than organizing committee and journalist/media team group; (3) Organizing committee has the higher level of expenditure compared to coach/athlete and journalist/media team group; (4) Journalist/media team group has the higher expenditure level than organizing team but the lower expenditure level than the two groups: audience and coach/athlete.

For "sightseeing cost", the difference in expenditure levels is statistically insignificant among these groups: (1) Audience group has the lower expenditure level than journalist/media team and coach/athlete group; (2) Coach/athlete group has the higher expenditure level than audience and journalist/media team group; (3) Organizing committee has the lower expenditure level than audience and journalist/media team group; (4) Journalist/media team group has the lower expenditure level than audience, coach/athlete and organizing committee group.

For "other cost", the difference in expenditure levels is statistically insignificant among these groups: (1) Audience group has the lower expenditure level than coach/athlete and journalist/media team group; (2) Coach/athlete group has the higher expenditure level than organizing committee, but its expenditure level is lower than that of journalist/media team group; (3) Organizing committee has the higher expenditure level than audience, but its expenditure level is lower than those of coach/athlete and journalist/media team group; (4) Journalist/media team group has the lower expenditure level than audience, coach/athlete and organizing committee group.

\section{Conclusion}

The analysis result of the difference in expenditure levels of different groups of participants at ABL 2014 shows that there are statistically significant differences in all types of direct expenses of all participant groups. Coach/athlete group has always the higher expenditure levels compared to organizing committee, audiences and journalist/media team group in terms of "accommodation cost", "shopping cost", "night entertainment cost". The research result is similar to that of previous published papers in Vietnam about economic impact.

There is statistically insignificant difference among these groups: organizing committee, coach/athlete, audience and journalist/ media team group in all types of direct expense at ABL 2014. More specifically, journalist/media team group and organizing committee have the higher expenditure levels than the other two groups: coach/athlete and audience group.

\section{References}

[1] Chappelet, J. L. 2005. "Sport and Economic Development." Present at the 2nd Magglingen Conference on Sport and Development 2008, Magglingen, Switzerland.

[2] Christopher, P. M. 1997. "Measuring the Economic Impact of Participants Involved in Community Sporting Events." Ph.D. thesis, The University of New Brunswick.

[3] Chris, G., Simon, S., and Richard, C. 2006. "The Economic Impact of Major Sports Events: A Review of Ten Events in the UK." Presented at the Editorial Board of the Sociologial Review, Blackwell publishing Ltd.

[4] Asian Basketball League. 2014. Saigon Heat Single Tickets. Accessed August 30, 2014. https://ticketbox.vn/saigon-heat-single-tickets-2016\&num $=1 \& \mathrm{hl}=\mathrm{vi} \& \mathrm{gl}=\mathrm{vn} \& \mathrm{strip}=1 \& \mathrm{vwsrc}=0$

[5] Steven, R. M. 2007. "Quantifying the Economic Impact of Community Events." Presented at MSU Extension Conference 2007 October 9-11, 2007, Michigan State University Kellogg Center East Lansing, MI.

[6] Huynh, T. T., and Bui, T. H. 2011. "Research on Economic Impacts of the 5th International VTV Volleyball Cup in 2011." In the 7th International 


\section{Asian Basketball League in Ho Chi Minh City}

Conference on Sport Science of University of Sport Ho Chi Minh City, 272-6.

[7] Trudo, D. 2006. "The Economic Impact of Sport."
Presented at Consultation Conference with the European Sport Movement on: The Role of Sport in Europe, Brussels, Belgium. 